Ambiances

anbiances Environnement sensible, architecture et espace urbain

3 | 2017

Animer l'espace public ? Entre programmation urbaine et activation citoyenne

\title{
Sonic territorialisation in motion. Reporting from the homeless occupation of public space in Grenoble
}

Territorialisation sonore en mouvement. Un reportage sur l'occupation sonore de l'espace public des sans-abri à Grenoble

Nicola Di Croce

\section{OpenEdition}

\section{Journals}

Electronic version

URL: http://journals.openedition.org/ambiances/1001

DOI: 10.4000/ambiances.1001

ISSN: 2266-839X

\section{Publisher:}

Direction Générale des Patrimoines - DAPA - MCC, UMR 1563 - Ambiances Architectures Urbanités (AAU)

\section{Electronic reference}

Nicola Di Croce, « Sonic territorialisation in motion. Reporting from the homeless occupation of public space in Grenoble », Ambiances [Online], 3 | 2017, Online since 10 December 2017, connection on 20 April 2019. URL : http://journals.openedition.org/ambiances/1001; DOI : 10.4000/ambiances.1001

This text was automatically generated on 20 April 2019.

\section{c)}

Ambiances is licensed under a Creative Commons Attribution-NonCommercial-NoDerivatives 4.0 International License. 


\title{
Sonic territorialisation in motion. Reporting from the homeless occupation of public space in Grenoble
}

\author{
Territorialisation sonore en mouvement. Un reportage sur l'occupation sonore \\ de l'espace public des sans-abri à Grenoble
}

Nicola Di Croce

\section{Introduction: exploring otherness through listening}

1 The urban sonic environment is constantly affected by socio-political issues. The aim of this paper is to explore the sonic effects of such issues in order to question hierarchical social spaces and to challenge public policies involved in social conflict. To this end, the socio-political dimension of everyday sounds produced by marginalised groups is analysed and contextualised within the urban pattern. In particular, homeless people in the city centre of Grenoble are considered the main recipient of "sonic awareness", and the main subjects for innovative, sound-based public policy propositions.

2 The case study developed in Grenoble contributes to reflections on the use and perception of public space, and to clarifying the role of "sonic marginality" within the urban environment. Exploring otherness becomes crucial: the occupation of specific public spaces by homeless populations shows how social conflicts can easily arise from reactions to the range of sonic expressions introduced by a group of "strangers" within one's everyday soundscape. In fact, the paper argues that the message of homeless populations is spread through dogs' barks, reprimands and yelling at dogs, as well as selflamentations and begging. These elements constitute a "language" that overwhelms the sonic environment through aural expressions, aggressive tones, and loud cues that may provoke and disturb normative life in the city. 
3 The idea of "disturbance" plays a crucial role here, as a means of negatively revealing what is "normal"; that is, the sonic environment shaped by marginal stakeholders such as homeless populations displays an alternative territory which interacts both with the city's inhabitants and the municipality. The sonic perception of otherness encourages reflection on how "norms" become policies, for whom they are made, and whom they exclude. Deleuze and Guattari's concept of "territorialisation" (Deleuze \& Guattari, 1987) helps to frame the sonic attitude of homeless people, and supports the investigation of how people relate to sonic marginality. Additionally, by borrowing from Foucault's framework of the heterotopia (Foucault, 2006), it is possible to consider sonic marginality as a sonic heterotopia, one which echoes the range of expressions diffused by marginalised stakeholders.

4 The aim of this paper is to demonstrate that the "language" produced by homeless populations systematically challenges any hierarchical territorialisation by diffusing audible heterotopias through sonic deterritorialisation. Within such a theoretical framework, the research claims that sonic studies can substantially contribute to reframing social conflicts by supporting anti-hierarchical social space (Lefebvre, 2003) through sensitive public policies. In order to do so, the field research was developed through careful investigation of the everyday sonic environment (Labelle, 2010) and through the analysis of various field recordings. Thus, relevant sonic cues were addressed by the inquiry as traces to be followed (Ginzburg, 1979), in order to unveil the urban atmospheres produced by different uses - and users - of public space (Thibaud, 2013; Griffero, 2013; Vazquez, 2013).

Social conflicts were finally analysed both from the urban and sonic perspectives (Kleinen et al., 2008; Pecqueux, 2013), while the question of homelessness was framed both in terms of ethnographic and psychology-based studies (Vexliard, 1957, 1998; Cefaï, 2015), and through the framework of spatial politics (Deutsche, 1998).

\section{Marginal stakeholders and sonic territorialisation in Grenoble}

Grenoble is located close to the Alps in the southeast of France, where the river Drac joins the Isère. It is the capital city of the department of Isère, in the Auvergne-Rhône-Alpes region, and is home to more than 600,000 residents in its metropolitan area. The public space of the inner city is articulated around several squares and parks. In particular, the Jardin de Ville is the public garden where every day, rounded cable cars, called Les Bulles, lead hundreds of tourists to the Bastille - an ancient fortification located on the mountainside overlooking Grenoble, and now one of the most famous attractions of the city. Just outside the Jardin, Place Grenette is among the most central and frequented squares in the city.

7 The area around Place Grenette and Jardin de Ville was selected as the central focus of the present research, on account of its contested sonic and social environment. The "elegant" atmosphere of the city centre is shaped in part by restaurants, shops, and shopping malls, such as Galerie Lafayette, and Fnac. At the same time, this area is subject to a surprising occupation of public space by homeless people. 
Groups of homeless people contribute to the composition a conflicting sonic environment that drives citizens' sonic perception and influences their relationship to public space. Such sonic occupation hides political repercussions that the present paper aims to unveil.

Illustration 1: Inner city overview: Place Grenette and Jardin de Ville

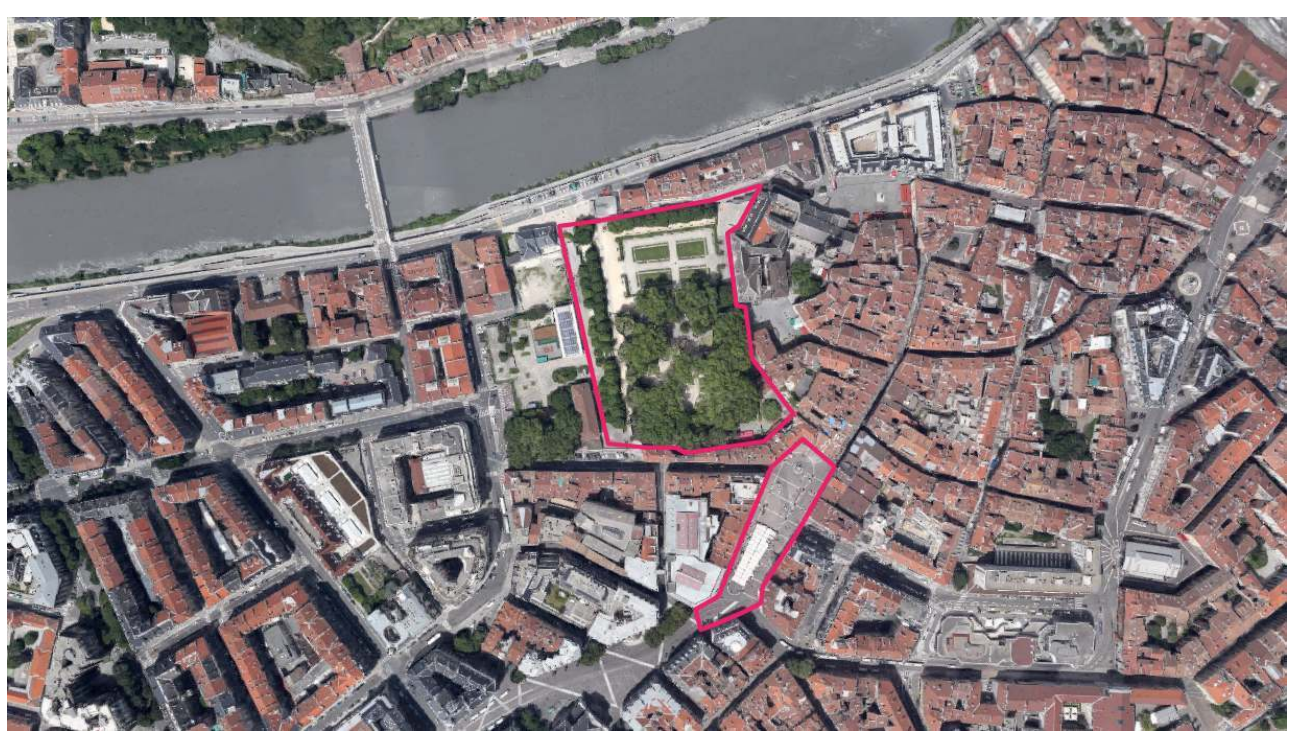

THE PURPLE LINES MARK THE LIMITS OF THE AREA EXPLORED BY THIS RESEARCH.

Source and copyright: Author's elaboration of the Google Map of Grenoble. (C) Google Maps.

The investigation of Grenoble's sonic environment demonstrates how certain kinds of activities, such as begging or occupation of space, occur readily in the city centre, where they are perhaps least to be expected. The inner city displays an articulated and contentious soundscape, which is difficult to find elsewhere. Nevertheless, public life in the main squares and parks (and, of course, in Place Grenette and Jardin de Ville) is vibrant and offers a wide range of activities: children's playgrounds, festivals and sports events reflect the ordinary and well-organised (sonic) environment. Within the inner city, such ordinary contexts echo the almost "undisturbed" sonic environment produced by the music coming from cafes and shops. The sonic hierarchy seems to favour the commercial focus of the area, and its upper middle class users.

10 I have gradually started to understand such sonic organisation as willing an incredible sense of normalcy that systematically tries to cover problematic social issues. The presence of a large number of homeless people, together with their dogs, constitutes a powerful weapon used to disturb the established order. The language diffused by homeless groups within the very core of the city creates an alternative sonic environment which is difficult to avoid.

This media file cannot be displayed. Please refer to the online document http:// journals.openedition.org/ambiances/1001

SOURCE AND COPYRIGHT: (C) NICOLA DI CROCE.

12 This field recording from Place Grenette perfectly illustrates the sonic occupation of public space by a group of homeless people: here, dogs act as a powerful device within homeless populations. Following Agamben's definition: 
"[a device is] literally anything which somehow has the capability to catch, guide, determine, intercept, shape, control, or guarantee the gestures, behaviours, opinions, and discourses of living beings." (Agamben, 2006, p. 22, author's translation)

13 It is thus possible to consider the language diffused by homeless groups as an articulated mix of human and animal expressions aiming at public acknowledgment. Voice (both human and animal) plays a central role: from playful to angry barking, from violent rebukes to delicate begging, from laments to screams, voices constantly shape the atmosphere of public space. To this end, Thibaud's words clarify the role of vocal expressions in the composition of urban ambiances:

"[...] the sheer plasticity and power of vocal expression in a given situation is perfect for pointing up the atmospheric nuances of places. This gives rise to various different impregnations that colour behaviour and sensitise experiences [...]." (Thibaud, 2013, p. 2)

14 During the field study, a large number of homeless people were camping in the Jardin, in Place Grenette, and within certain corners of the inner city. In these places, it was possible to experience the invisible borders created by their provocative sonic expressions. Such invisible limits are the results of the unmediated relationship between homeless people and the general population.

"Boundaries that consist of physical surfaces are tangible, readily apparent, and often have legal meaning. In contrast, sound is associated with invisible boundaries that demark the region within which a listener can hear people and events. This is an experimental delimiter, rather than a physical barrier." S. Blesser, in (Kleinen et al., 2008, p. 114)

15 As a result, social conflict may emerge because the range of expressions that a group of "strangers" introduces into the soundscape underlines their own marginalised conditions. Thus sonic otherness, as the result of social marginalisation, overlaps, provokes, and oppresses the "normal" sonic environment in the exact spaces where alternative "languages" are most evident, such as the city centre. The inner city seems both to be a protected environment, and a place where marginal stakeholders choose to express their identity.

This media file cannot be displayed. Please refer to the online document http:// journals.openedition.org/ambiances/1001

SOURCE AND COPYRIGHT: @ NICOLA DI CROCE.

This field recording, from Jardin de Ville, allows us to analyse and better clarify the social dynamics of the area. Jardin de Ville, which is linked to Place Grenette by a pedestrian passage, offers citizens a diverse range of activities, from a playground to a flower garden, and several grass spots often crowded with people. A group of homeless people and their dogs has its base under a kiosk just behind the flower garden. Within such a mixed environment, it is possible to listen to the simultaneous cues of different groups of people: a guitar player and his small audience, children running and shouting, adults chatting, the constant passage of wind through the branches. However, in this environment there are numerous sonic punctuations arising from groups of homeless people. The barking of dogs is especially evident because it triggers a reaction, usually the owners' loud rebukes. At the sound of yelling, many of the parks' activities are 
momentarily silenced, suggesting that the sonic presence of homeless people may reveal a temporarily tense atmosphere, which shortly disappears.

It is possible to further investigate such alternative sonic cues by introducing the notion of heterotopia. Every heterotopia is, according to Foucault's understanding, somehow institutionalised by a certain community. A heterotopia is the place where the idea of otherness is revealed. Cemeteries, mental hospitals, prisons, brothels - all these spaces play an ambivalent role and so were historically excluded from the city limits, but were nonetheless indispensable to the life of the city (Foucault, 1994). The sonic environment established by homeless groups, and especially their dogs, results in a violent soundscape that is unusual within the everyday perceived environment. This paper claims that such "disturbances" produced by barks and by the reactions they generate compensate for unresolved social issues. It is thus possible to use "sonic heterotopias" as a means of understanding the way marginalised groups challenge the syntax of the everyday environment by introducing an alternative language into the soundscape.

"Heterotopias are disturbing, probably because they secretly undermine language, because they make it impossible to name this and that, because they shatter or tangle common names, because they destroy 'syntax' in advance, and not only the syntax with which we construct sentences but also that less apparent syntax which causes words and things (next to and also opposite one another) to 'hold together'." (Foucault, 1994, pref. XVIII)

This media file cannot be displayed. Please refer to the online document http:// journals.openedition.org/ambiances/1001

SOURCE AND COPYRIGHT: () NICOLA DI CROCE.

In addition to the groups of homeless people, there are many homeless individuals scattered amongst the older streets, singing or lamenting, apparently without any recipient. This field recording, taken from Avenue Alsace Lorraine, a street connecting the inner city and the railway station, reveals an apparently suffering voice. This is the powerful complaint of a lonely homeless man, who addresses pedestrians with his marginalised condition. Such a range of expressions, though unusual and sometimes suspicious, does not in itself constitute a real risk for pedestrians. Sometimes, it fosters an improvised dialogue between homeless people and particularly curious or sensitive passers-by, whilst at other times it can constitute a perfect excuse to condemn such behaviour by the homeless.

21 It is interesting to notice that outside the core of the city centre, it becomes increasingly difficult to find groups of homeless people, as opposed to individuals. Place Grenette, Jardin de Ville and a few other streets within the inner city are thus the key areas of homeless people's occupation of public space. Such occupation has quite a small radius that mostly leaves the outskirts of the historical city, with the exception of the railway station and other isolated spots, unaffected. 


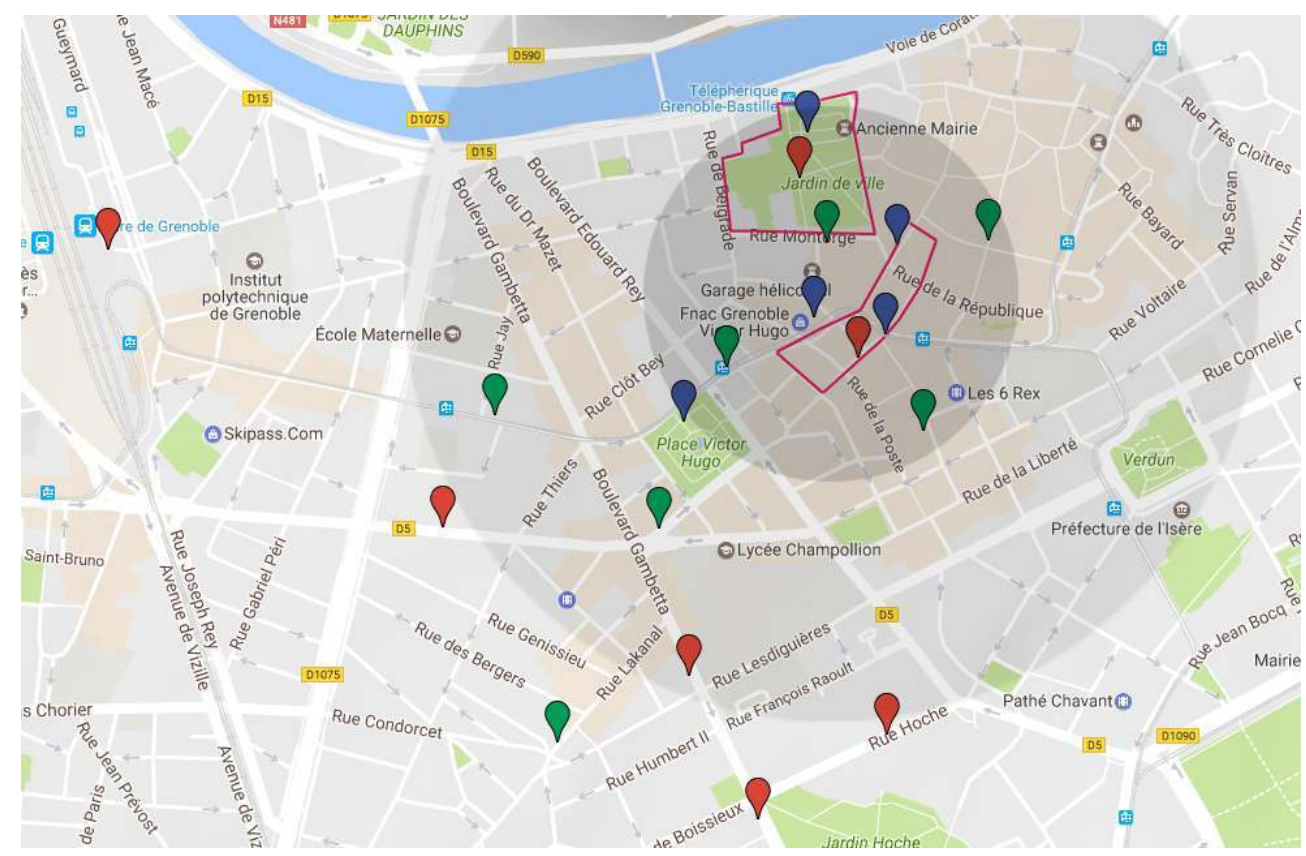

RED POINTERS INDICATE HOMELESS INDIVIDUALS; BLUE POINTERS INDICATE gROUPS WITH DOgS, gREEN POINTERS INDICATE HOMELESS PEOPLE LAMENTINg OR BEggINg.

SOURCE AND COPYRIgHT: AUTHOR'S ELABORATION OF THE GOOgLE MAP OF GRENOBLE. (C GOOgLE MAPS.

It is possible to argue, through the sonic investigation of Grenoble's inner city, that cohabitation and coexistence between inhabitants is strained by a particular sonic environment that recalls a plurality of stakeholders. Sonic otherness unveils a variety of meanings and feelings that affect people's sonic perception. It is for this reason that research is needed to clarify how citizens relate to the sonic heterotopia established by various social groups, and how important it is to safeguard any form of plural expression.

The idea of sonic heterotopia is tightly connected to Deleuze \& Guattari's concepts of territorialisation and deterritorialisation. Barks, screams, reprimands and lamentations compose a system of moving aural practices which challenges "normal" everyday life: that is to say, it moves from territorialisation to deterritorialisation. This definition of territorialisation helps to acknowledge which sonic environment is introduced by marginal stakeholders ("species"):

"Territorialisation is precisely such a factor that lodges on the margins of the code of a single species and gives the separate representatives of that species the possibility of differentiating. It is because there is a disjunction between the territory and the code that the territory can indirectly induce new species."

(Deleuze \& Guattari, 1987, p. 322)

What Deleuze and Guattari introduce as "code" is precisely the aural range of expressions that lead to deterritorialisation. In other words, the inhabitants of Grenoble (far from a homogeneous group), are constantly exposed to hierarchical territorialisation that the sonic expression of homeless people challenges. For example, the music diffused in the inner city by restaurants, cafes, and shops hides strong hierarchical and political meanings by acting as a "refrain": 
"The refrain is rhythm and melody that have been territorialised because they have become expressive - and have become expressive because they are territorialising." (Deleuze \& Guattari, 1987, p. 317) balanced by their polite way of begging. Through their sonic expressions, they largely state a voluntary detachment from society, rather than the will to "regain social position". It is possible then to say that homeless people seem to have consciously chosen their habits, which would suggest the frame proposed by social services does not fit such situation. As Cefaï underlines: “Social services work at bringing their 'clients' to accept the paradox that reaching autonomy implies the acceptance of a minimum of dependence on institutions." (Cefaï, 2015) paradox of social help, even if they seem to be resistant to changing their behaviour. Even the first phase proposed by Vexliard is inadequate to describe the current circumstances in Grenoble.

Cefaii's research is thus important to frame the present field study within a period of great changes for social services like Samusocial. Indeed, the actions of such services "became highly controversial. Its goals were reappraised, its methods partly changed and its 
perimeter restricted with the creation of the new stabilisation program." (Cefaï, 2015) As a result, those homeless people not in need of any kind of asylum and health care can become more resistant to any kind of institutional help, and perpetuate a sonic marginality that has not yet sought any institutional acknowledgment.

Besides social services intervention, the detachment of homeless populations from society is responsible for a marginal sonic environment that often provokes the day-today life of other inhabitants.

From the perspective of restaurant owners, for example, the inner city becomes "insecure" as soon as homeless people occupy a certain spot. At the same time, such occupation can cause people to change their trajectories, leading cafes to worry about moving occupation by the homeless. A segment of the public opinion is openly lined up against homeless occupation of public space. Especially in Place Grenette, informal organisations (like the Facebook Group: "Grenoble le changement") ${ }^{1}$, together with cafes and restaurant owners, are denouncing the lack of "respectability" of the city centre. At the same time, the residents complain about the volume of dogs' barking during the night, and denounce homeless occupation as an illegal practice: a "squat à ciel ouvert". These protests culminated in a public petition to expel homeless people from the main square, Place Grenette.

\section{Illustration 3: Pétition Place Grenette}

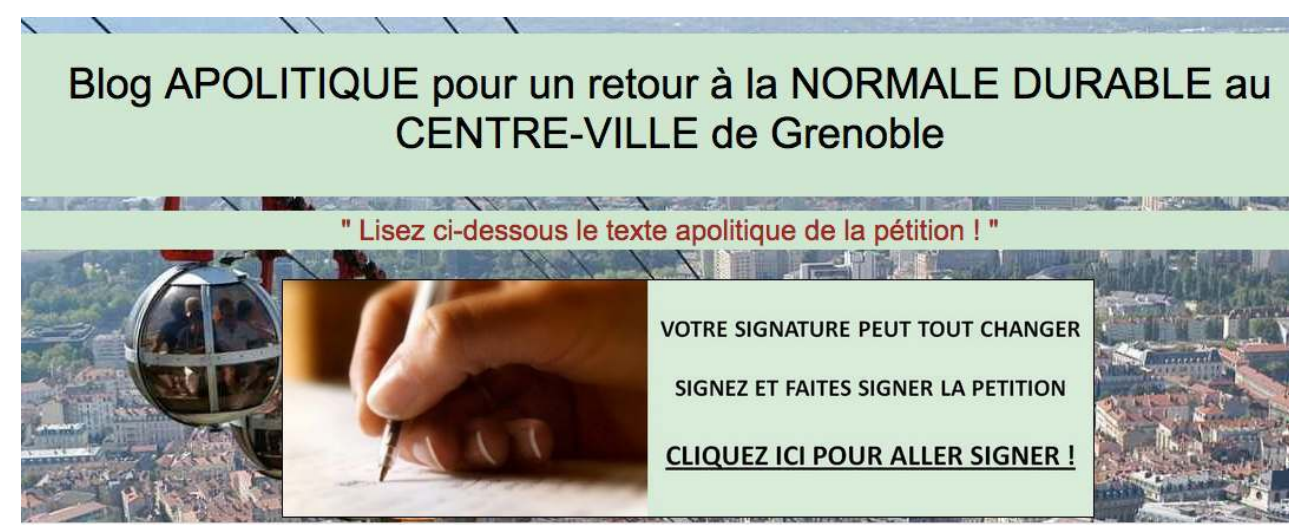

"Pétition Grenette"

SIGNEZ LA PETTIION UNIQUEMENT VIA CE BLOG.

Vous risquez de signer une vieille version en allant directement sur le site de pétition par Google.

VOTRE ADRESSE MALL RESTERA STRICTEMENT PRIIEEE. Le bouton "privé" est activé par défout sur le questionnaire de lo pétition Désactiver ce bouton est némonmins possible pour ceux quile souhaitent

QUI SOMMES NOUS?

Ce blog et cette pétition sont strictement apolitiques et concernent tous ceux qui portent intérêt au Centre Ville de Grenoble. Nous sommes au départ de simples habitants ou commerçants qui vivons quotidiennement le Centre-Ville de Grenoble, nous serons in fine l'ensemble des signataires de la pétition.

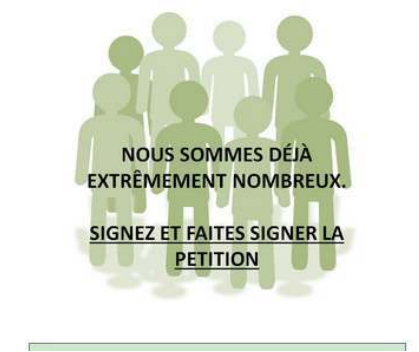

Source and copyright: Taken from "Blog Apolitique pour un retour à la Normale Durable au Centre-Ville de Grenoble" [online]. Available at: http://petitiongrenette.blogspot.fr/ (consulted on July 20, 2015).

In order to further investigate the consequences of citizen protests, the paper claims that it is not possible to simply consider homeless people's auditory expressions as noise pollution. The marginal sonic environment they create can be interpreted instead as a symptom of a lack of public dialogue aiming at human coexistence. La Belle's reflections about noise help to further such discussion: 
"[...] noise brings with it the expressiveness of freedom, particularly when located on the street, in plain view, and within public space; it may feature as a communication link by supporting the passing of often difficult or challenging messages; and in its unboundedness it both fulfils and problematises the sociality of architectural spaces by granting it dynamic movement and temporal energy. Noise can partially be heard to give form to the radical formless, creating space for the intensities of diversity, strangeness, and the unfamiliar." (Labelle, 2010, intr. XXIII)

Creating space for strangeness and diversity is precisely what can be derived from a deep understanding of sonic environment of homeless people. Unfortunately, the institutional solution to such controversial situations is typically police intervention, through which homeless people are simply kicked out of the places they occupy. By simply "moving along" its homeless populations, the municipality does not reach the root of the problem, nor seek public dialogue. Rather, I am convinced that issues of homelessness within the city must be faced neither through social order, nor through noise pollution control.

My research highlights sonic traces as symptoms of unresolved social issues, and suggests that public policies are central in reframing such debate. In particular, housing policies can be helpful to better clarify the relationship between homeless people's sonic environment, hierarchical territorialisation and citizens' complaints. In Cefaï's words, "Homelessness and poor housing were clearly connected in the minds of policymakers" (Cefaï, 2015), moving "social emergency" into housing policies.

this end, the history of immigration in Grenoble municipality can be of help in the present investigation. During 1931, southern European migrants - largely Italian - were mainly concentrated in the inner city. The ambiance of the old town was thus shaped by influxes of immigration for almost a century. Today, by choosing the city centre for their begging, homeless groups confirm the very core of the city to be heterotopic.

Through their everyday practices, they challenge the paradox of modern capitalism at its root and contribute to decreasing shop rents, and to a number of untenanted business venues.

As of 2011, the municipality of Grenoble has built nearly 17,000 social homes (40\% within the urban agglomeration), but more than $7 \%$ of these are currently vacant (Mairie de Grenoble, 2012). These data are evidently linked to vacancy and the decrease in rental incomes. It is possible to argue that the inner city is suffering economically because of marginalised stakeholders. It is for this reason that the powerful symbolic value of the historical centre is disputed by citizens and business owners who do not take into account the inner city's vocation to attract otherness.

the inner city, there is a large diffusion of occupied social centres (centre socia occupé autogéré) ${ }^{2}$, which play a strong role in the underground scene. This is a wide and well-organised "minority" that promotes a range of cultural activities, yet operates indoors and far from the inner city. As the underground scene does not work within the inner city, it does not produce any evident social impact throughout public space. This is because intractable conflicts arise precisely from interaction between the homeless and other population groups, which trigger a sense of belonging either to "majority" or "minority" positions.

In some other cases, the presence of homeless groups, as well as of other minorities, does not cause such conflict between citizens. Perhaps paradoxically, Jardin de Ville seems to be the place where different stakeholders find a way to express themselves despite such a mix. 
This media file cannot be displayed. Please refer to the online document http:// journals.openedition.org/ambiances/1001

SOURCE AND COPYRIgHT: (C) NICOLA DI CROCE.

this field recording, it is possible to hear the celebrations marking the beginning of Ramadan. The Jardin is chosen by muslims as the only public spot located in the centre of the city in which to organise an informal celebration. It is possible to notice multiple uses of the Jardin by different kinds of stakeholders: muslim people listening to music, young people singing, people playing ball, groups chatting and laughing. Furthermore, it is interesting to observe how no one seems to be annoyed by the presence of various marginalised groups such as homeless people or alcoholics who are sometimes yelling or moving around. In the Jardin, everyone is free to sing, to play music, or to laugh loudly, because the Jardin has become an open spot for sharing a common perception of otherness. Indeed, the popularity of the Jardin de Ville among the other parks shows how such a desire for peaceful coexistence is effectively fostering social integration between minorities (such as young people, immigrants, homeless people) who are looking for alternative "images of the city" (Radicchi, 2012; Lynch, 1964).

In conclusion, spatial hierarchies within Grenoble's inner city display a double perspective. On the one hand, Place Grenette represents the place where otherness is systematically suppressed by the "normal" sense of the place. On the other hand, the Jardin de Ville embodies the limits where marginal practices are tolerated yet never supported: in fact, alternative uses and users are threatened by the introduction of any sort of sport activities or music festivals that further limit any improvised uses of the garden. It is this relation of Grenoble to otherness which prompts this paper to propose a sharp reframing of the policy level of understanding.

\section{Why cities need otherness: outcomes and perspectives}

This paper claims that annoyance, tolerance or enjoyment of any marginal sonic environment belongs to, and deals with, sociopolitical frameworks. The field research reveals how sonic otherness is perceived differently according to age, socioeconomic status, interests and culture. It is a fact that only a segment of Grenoble's population is severely disturbed by the sonic deterritorialisation diffused by homeless populations. People experience public space in different ways. Otherness cannot be rejected or undervalued.

47 What therefore, should the sounds of a city centre or park be? In order to answer such a delicate question, it is crucial to challenge any hierarchical territorialisation of public space, and to explore the ways in which sonic environment can foster social integration between minority and majority positions.

Moving through atmospherology (Griffero, 2013) and psychoacoustics (Vazquez, 2010), one might acknowledge public policies as the institutional tools that can go beyond social differences and shape a truly plural and open environment.

In the light of these reflections, it is important to argue that cities are in need of "otherness", especially where public spaces that host alternative uses and users are 
threatened by economic or social demands. For example, marginalised stakeholders such as ethnic minorities are often searching for alternative contexts within which to safely practise their own sociality, but are often forced to use public space as they are unable to assert their own social position.

Every place dedicated to the free expression of marginalised stakeholders declares what the "right to the city" must permit (Lefebvre, 2003). Thus, sonic otherness becomes a "space of resistance": a liminal context where social and sonic thresholds can be experienced by the entire population.

51 Is it possible to design sensitive policies that aim to take care of such places dedicated to plural expression without enclosing them through inaccessible limits, and to do so without creating ghettos? What sort of innovative sonic "image of the city" could emerge from peaceful interaction open to conflict between hierarchical territorialisation and marginal deterritorialisation?

52 The inner city of Grenoble needs to find a balance between safeguarding marginal "language" and managing the social impact of plural expression. That is to say that sonic heterotopias cannot be condemned, but should rather direct the attention of citizens and institutions to the roots of specific issues.

53 To this end, issues around homelessness must be faced not as a problem of urban "decorum", but rather as a lack of communication between minorities and institutions, which needs to be substantially and sustainably addressed. In order to develop such a missing exchange, sonic studies can play a crucial role by proposing, for example, participatory sound art projects aimed at developing sonic awareness amongst citizens. Further research on the hidden relationship between citizens and the everyday sonic environment could in fact approach social conflicts through innovative and effective methodologies, and drive specific public policies.

More generally, institutions have the chance to take care of heterotopias within the city through public policies, on the premise of protecting and even supporting otherness. This would mean to say that social conflict is welcome as a manifestation of free expression, and its resolution must always involve public design processes.

Notions of "acceptance" and "noise pollution", then, need to be reframed from a wider sonic and political perspective. This is because the public discussion about any form of social integration is inevitable within the current socioeconomic situation. Here again, sonic studies can help to harmonise and inspire policies that directly deal with the public and that often need participatory design tools to become truly effective.

To this end, the public petition to expel the homeless from Place Grenette must be further discussed by all citizens, in order to find shared acknowledgment of the problem and its possible resolution. This could be achieved, for instance, through a participatory process held by the municipality of Grenoble, which would encourage the economic stakeholders such as cafes or restaurants to recognise sonic otherness as unavoidable within a contemporary city, and to perhaps establish peaceful dialogue with marginalised stakeholders.

In conclusion, this paper claims that an investigation of the sonic environment plays a central role in the political understanding of the city, because particular sonic traces represent symptoms of unresolved social issues. Thus, sonic studies have a role to play in supporting public policy design for the redefinition of such issues. Activating public space corresponds to the development of a participatory acknowledgment of different sonic 
frameworks proposed by various social groups. Within such frameworks, through the sonic acknowledgment of marginality, it is possible to identify otherness as a device for the formation of meaning. Listening to sonic heterotopias means approaching marginality in order to interpret its cues and imagine as yet untried political perspectives. In the light of this, issues around homelessness encourage the further development of the definition and importance of citizenship and the understanding of social inclusion. Listening deeply through the arena of conflicts can establish a new, sensitive social welfare, which could effectively challenge any processes of hierarchical territorialisation.

\section{BIBLIOGRAPHY}

Agamben, Giorgio. 2006. Che cos'è un dispositivo ? Roma: Nottetempo.

Cefaï, Daniel. 2015. Outreach work in Paris: A moral ethnography of social work and nursing with homeless people. Human Studies. vol. 38, n 1, p. 137-156.

Deleuze, Gilles \& Guattari, Felix. 1987. A Thousand plateaus. Capitalism and Schizophrenia. Minneapolis, London: University of Minnesota Press.

Deutsche, Rosalyn. 1998. Evictions: Art and Spatial Politics. Cambridge, MA: MIT Press.

Foucault, Michel. 1994. The order of things. An Archaeology of the Human Sciences. New York: Vintage Books.

Foucault, Michel. 2006. Utopie. Eterotopie. Naples: Cronopio.

Ginzburg, Carlo. 1979. Clues, roots of a scientific paradigm. Theory and society. vol. 7, $\mathrm{n}^{\circ} \mathrm{3}, \mathrm{p}$. 273-288.

Griffero, Tonino. 2013. The atmospheric "skin" of the city. Ambiances [online]. Available at: http://ambiances.revues.org/399 (consulted on July 25, 2015).

Kleinen, Doris; Kockelkorn, Anne; Pagels, Gesine \& Stabenow, Carsten. 2008. Tuned city. Zwischen Klang- und Raumspekulation / Between Sound and Space Speculation. Berlin: Kookbooks.

Labelle, Brandon. 2010. Acoustic Territories: Sound Culture and Everyday Life. New York: Continuum.

Lefebvre, Henri. 2003. The urban revolution, Minneapolis: Minnesota University Press.

Lynch, Kevin. 1964. L'immagine della città. Venice: Marsilio Editore.

Pecqueux, Anthony. 2013. Tempesta sonora o fuoco di campo sonoro: Do the Right Thing, interazione e ascolto musicale (in) pubblico. Studi Culturali. vol. 1, p. 53-70.

Radicchi, Antonella. 2012. Sull'immagine sonora della città. Firenze: Firenze University Press.

Thibaud, Jean Paul. 2003. The sonic composition of the city. In: Bull, Michael \& Back, Les (eds.). The Auditory Culture Reader. Amsterdam: Berg Publishers, p. 329-341.

Thibaud, Jean Paul. 2013. Giving voice to urban atmospheres. In: Carlyle, Angus \& Lane, Cathy. On Listening. Axminster: Uniformbooks, p. 75-78. 
Vazquez, Daniele. 2013. Il ruolo dei dispositivi nei divide socio-spaziali tra ricchi e poveri. [online]. Available at: http://www.luoghisingolari.net/teoria-sociale-spazio/2013/10/07/il-ruolo-deidispositivi-nei-divide-socio-spaziali-tra-ricchi-e-poveri/ (consulted on June 15, 2015).

Vexliard, A. 1998 [1957]. Le Clochard. Étude de psychologie sociale. Paris : Desclée de Brouwer.

\section{NOTES}

1. “Grenoble le changement". Facebook Group [online]. Available at: https://www.facebook.com/ pages/Grenoble-le-changement/204959392961783?fref=ts (consulted on July 20, 2015).

2. La Baf. centre social autogéré, Grenoble [online]. Available at: http://labaf.org/ (consulted on July 20, 2015).

\section{ABSTRACTS}

This research explores the political dimension of sonic environments within public space, with special attention on marginal stakeholders and their sonic behaviour. The aim is to investigate how public policies can relate to issues around the sonic environment and, more generally, how institutions can deal with social conflicts originated by a plurality of sonic perceptions. In order to do so, the paper presents the outcomes of field research developed in Grenoble in 2015, focusing on the "sonic deterritorialisation" of groups of homeless people in the inner city. The case study shows how certain kinds of everyday practices shape and affect sonic and public space and, in particular, the way in which sonic traces reveal social conflict. Homeless people's occupation of public space often involves a sonic challenge to the status quo, which pits marginal stakeholders, citizens, and city users against one another - reflecting the necessity to establish new forms of coexistence. "Sonic marginality" is thus the consequence of a lack of understanding. It constitutes a ground upon which a new sonic acknowledgment of "otherness" might develop, and points up the necessary role of sonic studies in better implementing political awareness, and to propose innovative resolutions for social conflict.

L'exploration de la dimension politique de l'environnement sonore dans l'espace public nous amène à nous focaliser sur les acteurs marginaux de la société et sur leur territorialisation sonore. Grâce à une méthodologie de recherche urbaine/sonore nous cherchons à répondre aux questions suivantes : quelles sont les traces sonores qui mettent en évidence les conflits sociaux? Est-ce possible de parler de marginalité sociale ou d'identifier des pratiques quotidiennes qui affectent l'espace public et sonore ? Une étude de cas effectuée à Grenoble, de mai à juillet 2015, nous offre l'occasion de réfléchir plus profondément à l'utilisation de l'espace public, au rôle des acteurs marginaux et à leurs pratiques quotidiennes qui donnent sans cesse forme à l'environnement sonore urbain. Le thème de "l'altérité » devient en conséquence crucial: l'occupation des espaces publics par les sans-abri montre comment les conflits sociaux peuvent émerger très facilement dans une gamme d'expressions introduites par un "étranger» de l'espace urbain; comment son langage se superpose, se mêle, provoque et écrase les pratiques quotidiennes des «autres" citoyens : chiens qui aboient, cris contre eux, plaintes et prières contribuent à une forte territorialisation sonore où la marginalité se manifeste de façon encore 
plus évidente dans l'espace public. Ces traces nous aident dans la recherche de création d'espaces sonores alternatifs.

\section{INDEX}

Mots-clés: territorialisation sonore, occupation de l'espace public, conflits sociaux, marginalité, altérité, sans-abri

Keywords: sonic deterritorialisation, occupation of public space, social conflict, marginality, otherness, homelessness

\section{AUTHOR}

\section{NICOLA DI CROCE}

Nicola Di Croce is an architect and a sound artist; he has a PhD in Regional Planning and Public Policy at the University of Venice. Di Croce's research focuses on marginal sonic environments and everyday practices. He has been a visiting doctoral student at Recomposing the City Research Centre, Belfast Queen's University, and at CRESSON, Grenoble University. Di Croce is the curator of the Italian Soundscape Archive collective (Archivio Italiano Paesaggi Sonori) and an active researcher within the fields of sonic studies and urban planning. His most recent publication is the essay Geografie sonore, published by Linaria Edizioni, Rome 2016.

nicoladicroce@yahoo.it 